\title{
Analgesic and Anti-Inflammatory Effects of Papaver Rhoeas L. A Traditional Medicinal Plant of Morocco
}

Hajjaj G1*, Bahlouli $A^{2}$, Tajani $\mathbf{M}^{3}$, Sayah $\mathbf{K}^{1}$, Cherrah $\mathrm{Y}^{1}$ and Zellou $\mathbf{A}^{1}$

${ }^{1}$ Laboratory of Pharmacology and Toxicology, Department of Drugs Sciences, Faculty of Medicine and Pharmacy, Mohammed University, ERTP, BP 6203, Rabat Instituts, Agdal, Rabat, Morocco.

${ }^{2}$ Laboratory of Biotechnology, Department of Biology, Faculty of Sciences, Ibn Tofaïl University, Morocco

${ }^{3}$ Laboratory of Biological Testing, Department of Biology, Faculty of Sciences, Ibn Tofaïl University, BP 133; 14000 Kenitra, Morocco

${ }^{*}$ Corresponding author: Ghizlane Hajjaj, Laboratory of Pharmacology and Toxicology, Department of Drugs Sciences, Faculty of Medicine and Pharmacy, Mohammed V University, ERTP, BP 6203, Rabat Instituts, Agdal, Rabat, Morocco, Email: Hajjajghizlane1@gmail.com

\section{Abstract}

Papaver rhoeas L. is an annual herb belongs to the Papaveraceae family that has not been investigated yet in Morocco. The flowers of this plant have been used in treating mild pain caused by earache, toothache and neuralgia, and an infusion of the petals is traditionally taken for coughs, insomnia and poor digestion.

In this study the toxicological effect of Papaver rhoeas L. aqueous extract (PRAE) was determined in mice. The toxicological results obtained indicated that $2000 \mathrm{mg} / \mathrm{kg}$ is LD50. Phytochemical screening of this plant revealed the presence of various bioactive secondary metabolites as tannins, saponins, terpenoids, flavonoids, and alkaloid. PRAE have been investigated for analgesic effects in acetic acid induced pain in mice and using tail flick in rats and for the antiinflammatory effects with the carrageen and experimental trauma-induced hind paw edema tests. Results demonstrated that Papaver rhoeas L. acts as a potent analgesic and anti-inflammatory agent in all tested models for analgesia and inflammation in Morocco.

Keywords: Analgesic Activity; Anti-inflammatory Effect; Aqueous Extract; Papaver rhoeas L.; Rodents

Abbreviations: PRAE: Papaver rhoeas L. Aqueous Extract

\section{Introduction}

Morocco is characterized by a great richness and diversity in aromatic and medicinal plants and it has an ancestral knowledge in the use of plants for medicinal and cosmetic purposes. The analysis of the bibliographic data showed that a large number of plants in Morocco are exploited for aromatic and medicinal purposes and several of them are commercialized internationally [1]. Papaver rhoeas L. is an annual herbaceous species of flowering plant in the poppy family, Papaveraceae. This 


\section{Journal of Natural \& Ayurvedic Medicine}

plant is a temperate native with a very wide area, from Africa, to temperate and tropical Asia and Europe. It grows in fields, beside roads and grasslands. Papaver rhoeas L. is very slightly narcotic. The chef constituent of the fresh petals is the red coloring matter, which consists of rhoeadic and papaveric acids this color is much darkened by alkalis. The genus name of this plant is from Latin papps and alludes to the thick milky latex found in the stems, the species name rhoeas may be from the latin rhoea, the common name of the red poppy, which may be a derivative of the greek rhoeo, to break or shatter, denoting the quick falling sepals, petals and seeds [2]. The medicinal uses of Papaver rhoeas L. are somewhat unclear. However, as early as the 11th century, Arab physicians used this plant as a cough remedy [3]. This plant is claimed to be useful in the treatment of respiratory problems, asthma, cough, loss of voice, hay fever, insomnia, and intestinal and urinary irritations $[3,4]$. Previous phytochemical investigations on this plant have revealed the presence of mainly various alkaloids [57]. As part of our on-going screening of plant extracts for activities the purpose of this study was to investigate about the preliminary phytochemical screening of Papaver rhoeas L. and to evaluate analgesic and antiinflammatory activities of Papaver rhoeas L. aqueous extract in rodents.

\section{Materials and Methods}

\section{Plant Material}

Aerial parts of Papaver rhoeas L. were collected in and around Sidi Yahya in Morocco in the month of April 2016. The specimen was identified at the Department of Plant Biology, Ibn Tofail University, Morocco and Voucher specimen $\left(\mathrm{N}^{\circ}\right.$ Rab 7313) was kept in the herbarium of Botany Department of Scientific Institute of Rabat. The plant leaves were thoroughly washed with tap water to avoid dusts and other unwanted materials accumulated on the leaves from their natural environment. The dust free leaves were allowed to dry under shade in the botany laboratory. The dried leaves were powdered by using electric blender. Finally, fine powder was collected from the powdered leaves by sieving through the kitchen strainer and used for extraction [8].

\section{Preparation of Aqueous Extract}

$50 \mathrm{~g}$ of powdered material of Papaver rhoeas L. was taken in beaker having $2 \mathrm{~L}$ capacities and $500 \mathrm{ml}$ of distilled water was added, soaked for $48 \mathrm{~h}$ with occasional shaking and stirring. The soaked material of plant was filtered through several layers of muslin cloth one by one for coarse filtration. The filtered extracts were concentrated under reduced pressure at $40^{\circ} \mathrm{C}$, in rotary evaporator. The semi-solid mass was obtained and was weighed to calculate the yield, which was $13.76 \%(\mathrm{w} / \mathrm{w})$ respectively and stored in a refrigerator $\left(-8^{\circ} \mathrm{C}\right)$, until use $[9,10]$.

\section{Phytochemical Screening}

Phytochemical properties of Papaver rhoeas L. were tested according to the method described by trease and Evans (1983) using the following chemicals and reagents: Alkaloids with Mayer and Dragendoff's reagents, Saponins (frothing test) and tannins ( $\mathrm{FeCL}_{3}$ ), flavonoids ( $\mathrm{Nacl}$ and HCL), terpenoids (Salkowski test), anthraquinones $\left(\mathrm{H}_{2} \mathrm{SO}_{4}\right)[11,12]$.

\section{Animals}

Rats (180-220 gm each) and mice (20-25 gm each) of either sex used in this study were housed in the animal center of Mohammed $V$ University, Medicine and Pharmacy Faculty, Rabat, Morocco. Animals were given tap water ad libitum and maintained under standard conditions at $23 \pm 1{ }^{\circ} \mathrm{C}$ and relative humidity $60-70 \%$ and 12h-dark/12h-light cycle. The investigation was conducted in accordance with the Official Journal of the European Committee in 1991 and approved by the Institutional Research Committee regarding the care and use of animals for the experimental procedure in 2010; CEE509 [13,14].

\section{Acute Toxicity Test}

LD50 values were determined as described by OECD 423 this method is preferred because fewer animals are required [15]. Median lethal dose (LD50) of the aqueous extract was determined using female Swiss mice. The aqueous extract was dissolved in distilled water and given by orally way in a single dose ( $2 \mathrm{gm} / \mathrm{kg}$, p. o.) of body weight. Mice were observed for clinical effects and mortality during 14 days [16].

\section{In vivo Analgesic Activity}

Acetic acid-induced writhing test: The test was performed according to Koster Test [17]. Nociception was induced by an intraperitoneal (i. p.) injection of 0.1 $\mathrm{mL} / 10 \mathrm{gm}$ acetic acid solution (3\% with $300 \mathrm{mg} / \mathrm{kg}$ ). Positive control animals were pretreated with aspirin (200 mg/kg, p. o.) $30 \mathrm{~min}$ before acetic acid. The aqueous extract of Papaver rhoeas L. was administered in different doses at 200 and $400 \mathrm{mg} / \mathrm{kg}$ p. o. to the Swiss mice after an overnight fast. Five minutes after the i. p. injection of 


\section{Journal of Natural \& Ayurvedic Medicine}

acetic acid, the number of writhing and stretching was recorded during $20 \mathrm{~min}$.

Tail immersion test: This experiment was done based on the previous observation demonstrating that morphinelike analgesics prolongs the tail withdrawal latency from hot water in rodents $[18,19]$. Rats that showed tail withdrawal time between 1.5 and $2 \mathrm{~s}$ were selected for this experiment, and the pretreatment latency was recorded. Then rodents were pretreated with morphine or aqueous extract of Papaver rhoeas L. and 4 to $5 \mathrm{~cm}$ of their tail was immersed in the warm water with a constant temperature of $55^{\circ} \mathrm{C}$. The time between tail submersion and tail deflection was recorded at 15, 30, 45, 60 and $120 \mathrm{~min}$ after the treatment with standard drug or extract. A cut-off time of $10 \mathrm{~s}$ was maintained to avoid tail tissue damage in the rodents.

\section{Anti-Inflammatory Activity}

Carrageenan-induced rat paw edema: Carrageenaninduced hind paw edema model was used to determine the anti-inflammatory activity [20,21]. Animals were treated with the aqueous extract of Papaver rhoeas L. at doses 400 and $800 \mathrm{mg} / \mathrm{kg}$ p.o., Indomethacin $(10 \mathrm{mg} / \mathrm{kg})$ or normal control, $60 \mathrm{~min}$ prior to injection of $1 \%$ carrageenan $(50 \mu \mathrm{l})$ in the plantar side of left hind paws of the rats. Paw volume was measured after Carrageenan injection at $1 \mathrm{~h} 30,3 \mathrm{~h}$, and $6 \mathrm{~h}$ using a plethysmometer (model 7500, Ugo Basile).

\section{- Percent inhibition of the edema was calculated as} $\%$ of inhibition= mean [v Left_v Right] control-[v Left_v Right] treated / [v Left_v Right] control × 100.

$V$ Left means the volume of edema on the left.

V Right means the volume of edema on the right.

Experimental Trauma-Induced Rat Paw Edema: In this test the anti-inflammatory properties were investigated by using mechanical stimuli (Riesterer and Jaques Test) [22]. Rats were given indomethacin $(20 \mathrm{mg} / \mathrm{kg} \mathrm{p.} \mathrm{o.)} \mathrm{and}$ aqueous extract $(400,800 \mathrm{mg} / \mathrm{kg}$ p. o.) $1 \mathrm{~h}$ before dropping a weight of $50 \mathrm{gm}$ onto the dorsum of the left hind paw of all rats. The right hind paw is not treated; it is taken as a witness. The paw volume was measured immediately before and at $1 \mathrm{~h} 30,3 \mathrm{~h}$ and $6 \mathrm{~h}$ after treatment by means of volume displacement methods using a 7500 Ugo Basile Plethysmometer. The difference between the left paw and right paw volumes indicated the degree of inflammation. The average percentage increase in paw volume of each group was calculated and compared with the control group and the indomethacin group.
- The percentages of inhibition of inflammation were calculated according to the following formula:

\% of inhibition=mean [v Left _ $v$ Right] control [v Left _ v Right] treated / [v Left_ $v$ Right] control $\times 100$.

\section{Statistical Analysis}

Values were presented as mean \pm SEM and were analyzed by one-way analysis of variance (ANOVA), following by student's t-test. All differences showing a ${ }^{*} \mathrm{p}<0.05$ were accepted as statistically significant.

\section{Result}

\section{Phytochemical Study}

All results of phytochemical analysis are showed in the Table 1.

The present study revealed that the phytochemical screening showed positive results for Tannins, Saponins, and Terpenoids with high degree of precipitation (+++). Flavonoids, and alkaloids were determined to be present with lesser amount (+) only in this plant.

\begin{tabular}{|c|c|}
\hline Phytochemicals & Papaver rhoeas \\
\hline Tannins & +++ \\
\hline Flavonoids & + \\
\hline Saponins & +++ \\
\hline Alkaloids & + \\
\hline Terpenoids & +++ \\
\hline Anthraquinones & - \\
\hline
\end{tabular}

Table 1: Phytochemical screening of Papaver rhoeas L. aerial parts.

\section{Acute Oral Toxicity Study}

No adverse effect or mortality was detected in Swiss mice at $2 \mathrm{~g} / \mathrm{kg}$ of Papaver rhoeas $\mathrm{L}$. aqueous extract. All the animals were alive, healthy and active during the observational period of 14 days. So the LD 50 was considered as $>2000 \mathrm{mg} / \mathrm{kg}$.

\section{In vivo Analgesic Activity}

Acetic acid induced writhing test: The results obtained with acetic acid-induced writhing are shown in Table 2. All doses administered (200 and $400 \mathrm{mg} / \mathrm{kg}$, p.o.) had a significant $(\mathrm{P}<0.05)$ effect on the number of abdominal constrictions, promoting 20.25, 12.25 writhing and $60.29 \%$ and $75.98 \%$ inhibition, respectively, as compared with the control group treated with distilled water. 


\section{Journal of Natural \& Ayurvedic Medicine}

Aspirin at a dose of $200 \mathrm{mg} / \mathrm{kg}$ (p.o.) reduced the writhing inhibition.

count (45 to 19.6) in 20 minutes showing $61.56 \%$

\begin{tabular}{|c|c|c|c|}
\hline Treatment groups & Dose $\mathbf{~ m g} / \mathbf{k g}$ p.o. & No of writhing & Percent of inhibition (\%) \\
\hline Control & $0,5 \mathrm{ml} /$ mouse & $45 \pm 2.58$ & - \\
\hline Aspirin & 200 & $19.6 \pm 2.88^{*}$ & 61.56 \\
\hline AEPR & 200 & $20.25 \pm 3.21^{*}$ & 60.29 \\
\hline AEPR & 400 & $12.25 \pm 2.40^{*}$ & 75.98 \\
\hline
\end{tabular}

Table 2: Effect of Papaver rhoeas L. on acetic acid induced writhing in mice.

Values are means \pm S.E.M. * $\mathrm{P}<0.05$, significantly different from control; Student's t-test $(n=6)$.

Tail flick test: Table 3 shows the results obtained for Tail flick Test. There was no significant difference between mean reaction time of different groups $(\mathrm{P}>0.05)$ at $0 \mathrm{hr}$. Test groups showed increase in the reaction time significantly after $15 \mathrm{~min}$ in the doses of $400 \mathrm{mg} / \mathrm{kg}$ and
$800 \mathrm{mg} / \mathrm{kg}$ body weight, per orally compared to the control group. AEPR at the dose of 400 and $800 \mathrm{mg} / \mathrm{kg}$ body weight, per orally showed highly significant increase in reaction time at $30 \mathrm{~min}$ (reaction time 7.32 and 9.72 seconds respectively, $\mathrm{P}<0.05)$.

\begin{tabular}{|c|c|c|c|c|c|c|}
\hline \multicolumn{7}{|c|}{ Reaction Time in Seconds } \\
\hline Treatment /Dose & $0 \mathrm{~min}$ & $15 \mathrm{~min}$ & $30 \mathrm{~min}$ & $45 \mathrm{~min}$ & $60 \mathrm{~min}$ & $120 \mathrm{~min}$ \\
\hline Control & $1.57 \pm 0.13$ & $1.62 \pm 0.1$ & $1.63 \pm 0.09$ & $1.65 \pm 0.13$ & $1.54 \pm 0.14$ & $1.45 \pm 0.14$ \\
\hline Morphine $5 \mathrm{mg} / \mathrm{kg}$ & $1.78 \pm 0.19$ & $3 \pm 0.15$ & $5.5 \pm 0.19$ & $7.49 \pm 0.15$ & $5.05 \pm 0.14$ & $3 \pm 0.13$ \\
\hline AEPR $400 \mathrm{mg} / \mathrm{kg}$ & $1.65 \pm 0.13$ & $5.82 \pm 0.28^{*}$ & $7.32 \pm 0.2^{*}$ & $4.66 \pm 0.7^{*}$ & $3.35 \pm 0.29$ & $3.15 \pm 0.15$ \\
\hline AEPR $800 \mathrm{mg} / \mathrm{kg}$ & $1.70 \pm 0.73$ & $4.83 \pm 0.65^{*}$ & $9.72 \pm 0.45^{*}$ & $5.06 \pm 0.32^{*}$ & $4.71 \pm 0.16^{*}$ & $4.013 \pm 0.21$ \\
\hline
\end{tabular}

Table 3: Central Analgesic activity of Papaver rhoeas L. by Tail immersion test.

Values are means \pm S.E.M. ${ }^{*} \mathrm{P}<0.05$, significantly different from control; Student's t-test $(n=6)$ AEPR: Aqueous extract of Papaver rhoeas L.

\section{Anti-Inflammatory Activity}

Carrageenan-induced rat paw edema: The aqueous extract of Papaver rhoeas L. at a dose of $400 \mathrm{mg} / \mathrm{kg}$, showed $87.47 \%, 86.99 \%$ and $75.65 \%$ inhibition at $1 \mathrm{~h} 30-$ $6^{\text {th }}$ hour Mean while Aqueous extract administered at a dose of $800 \mathrm{mg} / \mathrm{kg}$, showed $87.47 \%, 87.49 \%$ and $83.61 \%$ inhibition at $1 \mathrm{~h}$ 30-6 $6^{\text {th }}$ hour respectively while Indomethacin at a dose of $10 \mathrm{mg} / \mathrm{kg}$ p.o. prevented carragenan induced paw edema with a percentage inhibition of $64.24 \%, 74.14 \%, 63.59 \%$, at $1 \mathrm{~h} 30-6$ th hour respectively (Table $4 \& 5$ ).

\begin{tabular}{|c|c|c|c|c|}
\hline \multirow{2}{*}{ Treatment groups n=6 } & \multirow{2}{*}{ Dose mg/kg p.o. } & \multicolumn{3}{|c|}{ Mean volume of edema (paw left-paw right) induced by } \\
\cline { 3 - 4 } & & $1 \mathrm{~h} 30$ & $3 \mathrm{~h}$ & $6 \mathrm{~h}$ \\
\cline { 3 - 5 } & - & $0.386 \pm 0.01$ & $0.581 \pm 0.00$ & $0.478 \pm 0.01$ \\
\hline Control & 10 & $0.115 \pm 0.003^{*}$ & $0.15 \pm 0.006^{*}$ & $0.165 \pm 0.007^{*}$ \\
\hline Indomethacin & 400 & $0.036 \pm 0.13^{*}$ & $0.055 \pm 0.13^{*}$ & $0.075 \pm 0.05^{*}$ \\
\hline AEPR & 800 & $0.038 \pm 0.11^{*}$ & $0.06 \pm 0.061^{*}$ & $0.054 \pm 0.089^{*}$ \\
\hline AEPR & &
\end{tabular}

Table 4: Effect of Papaver rhoeas L. on carrageenan-induced rat paw edema. 


\section{Journal of Natural \& Ayurvedic Medicine}

Values are expressed as mean \pm S.E.M. $(n=6)$, AEPR: aqueous extract of Papaver rhoeas L., ${ }^{*} \mathrm{P}<0.05$ statistically significant compared to the control and reference drug (Indomethacin).

\begin{tabular}{|c|c|c|c|c|}
\hline \multirow{2}{*}{ Treatment groups n=6 } & \multirow{2}{*}{ Dose mg/kg p.o. } & \multicolumn{3}{|c|}{$\begin{array}{c}\text { Percent of Inhibition of Inflammation Induced By } \\
\text { carrageenan (\%) }\end{array}$} \\
\cline { 3 - 5 } & & $1 \mathrm{~h} 30$ & $3 \mathrm{~h}$ & $6 \mathrm{~h}$ \\
\hline Control & - & - & - & 63.59 \\
\hline Indomethacin & 10 & 64.24 & 74.14 & 75.65 \\
\hline AEPR & 400 & 87.47 & 86.99 & 83.61 \\
\hline AEPR & 800 & 87.47 & 87.49 & - \\
\hline
\end{tabular}

Table 5: Percentage of inhibition of inflammation of Papaver rhoeas L. using carrageenan-induced rat paw edema. $N=6$; these results compared with standard drug (Indomethacin, $10 \mathrm{mg} / \mathrm{kg}, \mathrm{p.o.}$.) were administered by the oral route.

Experimental trauma-induced rat paw edema: Table 6 \& 7 shows that all Papaver rhoeas L. doses significantly decreased the inflammation compared to controls, with the maximum effect at 3 hour produced by $400 \mathrm{mg} / \mathrm{kg}$
(94.95\%) and $800 \mathrm{mg} / \mathrm{kg}$ (94.73\%). Meanwhile, 20 $\mathrm{mg} / \mathrm{kg}$ of indomethacin significantly inhibited inflammation compared to controls, and the largest effect was $(83.62 \%)$.

\begin{tabular}{|c|c|c|c|c|}
\hline \multirow{2}{*}{ Treatment groups n=6 } & \multirow{2}{*}{ Dose mg/kg p.o. } & \multicolumn{3}{|c|}{ Mean volume of edema (paw left-paw right) Induced By } \\
& & $1 \mathrm{~h} 30$ & $3 \mathrm{~h}$ & $6 \mathrm{~h}$ \\
\cline { 3 - 5 } & - & $0.441 \pm 0.01$ & $0.693 \pm 0.01$ & $0.563 \pm 0.01$ \\
\hline Control & 20 & $0.09 \pm 0.006^{*}$ & $0.102 \pm 0.008^{*}$ & $0.142 \pm 0.006^{*}$ \\
\hline Indomethacin & 400 & $0.032 \pm 0.08^{*}$ & $0.027 \pm 0.04^{*}$ & $0.06 \pm 0.115^{*}$ \\
\hline AEPR & 800 & $0.034 \pm 0.06^{*}$ & $0.032 \pm 0.017^{*}$ & $0.05 \pm 0.06^{*}$ \\
\hline AEPR & &
\end{tabular}

Table 6: Effect of aqueous extract of Papaver rhoeas L.on experimental trauma-induced rat paw edema.

Values are expressed as mean \pm S.E.M. $(n=6)$, AEPR: aqueous extract of Papaver rhoeas $L ., * P<0.05$ statistically significant compared to the control and, reference drug (Indomethacin).

\begin{tabular}{|c|c|c|c|c|}
\hline \multirow{2}{*}{ Treatment groups n=6 } & \multirow{2}{*}{ Dose mg/kg p.o. } & \multicolumn{3}{|c|}{$\begin{array}{c}\text { Percent of Inhibition of Inflammation Induced By } \\
\text { Experimental Trauma (\%) }\end{array}$} \\
\cline { 3 - 5 } & & $1 \mathrm{~h} 30$ & $3 \mathrm{~h}$ & $6 \mathrm{~h}$ \\
\hline Control & - & - & - & - \\
\hline Indomethacin & 20 & 79.55 & 83.62 & 83.16 \\
\hline AEPR & 400 & 90.78 & 94.95 & 84.2 \\
\hline AEPR & 800 & 88.09 & 94.73 & \\
\hline
\end{tabular}

Table 7: Percentage of inhibition of inflammation of Papaver rhoeas L. using experimental trauma-induced rat paw edema.

$N=6$; these results compared with standard drug (Indomethacin, $20 \mathrm{mg} / \mathrm{kg}, \mathrm{p.o.}$ ) were administered by the oral route. 


\section{Journal of Natural \& Ayurvedic Medicine}

\section{Discussion}

This study was undertaken to investigate the aqueous extract of Papaver rhoeas L. at doses 400 and $800 \mathrm{mg} / \mathrm{kg}$ $(-1)$ p.o. for analgesic and anti-inflammatory activities. The analgesic effect was studied using acetic acid-induced abdominal constriction in mice and tail immersion test in rats, while the anti-inflammatory effect was investigated using carrageenan and experimental Trauma- induced paw oedema in rats.

The extract of Papaver rhoeas L. showed statistically significant $(\mathrm{P}<0.05)$ analgesic activity at all tested dose levels and it also exhibited significantly $(\mathrm{P}<0.05)$ antiinflammatory effect. The preliminary phytochemical screening of the plant extract revealed the presence of Flavonoids, Terpenoids, Tannins, Alkaloids and Saponins while the effect of flavonoids, saponins and tannins on analgesic and inflammatory has been reported. In the analgesic effect against acetic acid induced visceral pain, the characteristic of pain activity is presented with contraction of abdominal muscle followed by extension of hind limbs and elongation of body part and such constriction is thought to be mediated by local peritoneal receptor [23]. The acetic acid provoked writhing is simple and commonly used method for screening analgesic drugs [24]. In the tail immersion method [25], The behavior of pain resulting from this method is based on reflex mediated at spinal level which is considered more sensitive to other thermal nociceptive models like hot plate method $[26,27]$.

This method has also advantage of differentiating central opioid-like analgesics from peripheral analgesics [28]. In our study we believe that the analgesic activity of the extract may therefore be due to either its action on the peritoneal receptors, the inhibition of the production of arachidonic acid metabolites or the inhibition of synaptic transmission of painful messages to the central nervous system. In the anti-inflammatory effect, the carrageenan and experimental-Trauma induced rat paw edema is commonly used as an experimental animal model to evaluate the anti-inflammatory potential of natural products and is believed to be biphasic. The initial phase is due to the release of histamine, serotonin and kinin in the first hour after administration of carrageenan or trauma. Second phase is attributed to release of bradykinin, prostaglandin and lysosome [29] Saponins are reported to have anti-inflammatory effects supported by the reduction of carrageen an induced lipid peroxidation and hydroxyl radical content in rat serum [30].
In previous study certain flavonoids possess potent inhibitory activity against a wide array of enzymes and prostaglandins [31-32] also in another study some tannins have been shown to inhibit the inflammatory events which occur at the onset of hemorrhagic cystitis. The coexistence of both analgesic and anti-inflammatory effects seen with this extract is well defined for various non-steroidal anti-inflammatory drugs (NSAIDs) since the cyclooxygenase enzyme which leads to the production of prostanoids is usually inhibited. Our results suggest that the extract has NSAID-like activity which correlates with the traditional use of the plant. The result obtained from this study shows that aqueous extract of Papaver rhoeas $\mathrm{L}$. contained phytochemical constituents with analgesic and anti-inflammatory activities, therefore this plant could be used in the management of pain and inflammatory conditions in Morocco.

\section{Conclusion}

In conclusion, Papaver rhoeas L. in a dose-dependent pattern was effective in attenuating pain and inflammation in rodent models, and therefore it could be investigated as a potential treatment for pain and chronic inflammatory conditions in humans.

\section{Acknowledgement}

The authors wish to thank all the individuals and institutions who made this survey possible.

Conflict of Interests: Declared none.

\section{References}

1. Taleb MS (2017) Aromatic and Medicinal Plants in Morocco: Diversity and Socio-Economic Role. International Journal of Agricultural \& Biosystems Engineering 11(12): 812- 816.

2. Ghizlane H, Aziz BB (2016) Pharmacological properties of some medicinal plants, its components and using fields Fruits, Vegetables, and Herbs, Bioactive Foods in Health Promotion, pp: 41-56.

3. Howard M (1987) Traditional Folk Remedies, a Comprehensive Herbal. Century Hutchinson, London.

4. Potterton D, Stringer M (1996) Culpepers Colour Herbal. Foulsham, DNP CD-ROM, London, pp: 16-243. 


\section{Journal of Natural \& Ayurvedic Medicine}

5. ISI Database (2004) Institute for Scientific Information, UK.

6. Kalav YN and Sariyar G (1989) Alkaloids from Turkish Papaver rhoeas. Planta Medica 55(5): 488.

7. El-Masry S, El-Ghazooly MG, Omar AA, Khafagy SM, Philipson JD (1981) Alkaloids from Egyptian Papaver rhoeas. Planta Medica 41(1): 101-105.

8. Ghizlanehajjaj, Bahlouli A, Mounatajani, Cherrah Y, Zellou A (2016) In vivo Anti-nociceptive and Antiinflammatory properties of Ormenismixta $L$. from Morocco. International Journal of Pharmacy and Pharmaceutical Sciences 8(5): 49-52.

9. Hajjaj G, Bounihi A, Tajani M, Cherrah Y, Zellou A (2013) Anti-inflammatory evaluation of aqueous extract of Matricaria chamomilla L. (asteraceae) in experimental animal models from Morocco. World J Pharm Res 2(5): 1218-28.

10. Hajjaj G, Bounihi A, Tajani M, Cherrah Y, Zellou A (2014) In vivo analgesic activity of essential oil and aqueous extract of Matricaria chamomilla $L$. (asteraceae). World J Pharmacy Pharm Sci 5: 1-13.

11. Trease GE, Evans WC (1983) Textbook of Pharmacognosy, 12 ${ }^{\text {th }}$ (Edn.), Balliese Tindall and Company Publisher, London, pp: 343-383.

12. Uddin G, Rauf A, Siddiqui BS, Shah SQ (2011) Preliminary Comparative Phytochemical Screening of Diospyros lotus Stewart. Middle-East Journal of Scientific Research 10(1): 78-81.

13. Ghosh MN (1984) Fundamentals of experimental pharmacology, 2 $2^{\text {nd }}$ (Edn.), Scientific Book Agency, Calcutta, pp: 178-210.

14. (1986) Journal Officiel des communautés européennes. The directive, 86/609/CEE.

15. (2011)OECD Guidelines for the Testing of Chemicals (No. 423)"Acute Oral Toxicity-Acute Toxic Class Method".

16. Hajjaj G, chakour R, Bahlouli A, Tajani M, Cherrah Y, et al. (2018) Evaluation of CNS Activity and AntiInflammatory Effect of Pistacia atlantica desf. Essential Oilfrom Morocco. The Pharmaceutical and Chemical Journal 5(3): 86-94.
17. Koster R, Anderson M, Debeer EJ (1959) Acetic acid for analgesic screening. Fed Proc 18: 412.

18. Dykstra LA, Woods JH (1986) A tail withdrawal procedure for assessing analgesic activity in Rhesus monkeys. J Pharmacol Methods 15(3): 263-269.

19. Winter CA, Risley EA, Nuss GW (1962) Carrageenaninduced oedema in the hind paw of the rat as an assay for anti-inflammatory activity. Proc Soc Exp Biol Med 111: 544-547.

20. Hajjaj G, Bounihi A, Tajani M, Cherrah Y, Zellou A (2013) Anti-inflammatory evaluation of aqueous extract of Matricaria chamomilla L. (asteraceae) in experimental animal models from Morocco. World J Pharm Res 5: 1218-1228.

21. Riesterer L, Jaques R (1970) The influence of antiinflammatory drugs on the development of an experimental traumatic paw oedema in the rat. Pharmacology 3(4): 243-251.

22. Bentley GA, Newton SH, Starr J (1983) Studies on the antinociceptive action of $\alpha$-agonist drugs and their interactions with opioid mechanisms. Br J Pharmacol 79(1): 125-134.

23. Collier HO, Dinneen LC, Johnson CA, Schneider C (1968) The abdominal constriction response and its suppression by analgesic drugs in the mouse. $\mathrm{Br} \mathrm{J}$ Pharmacol Chemother 32(2): 295-310.

24. Vogel H (2007) Drug Discovery and Evaluation: Pharmacological Assays. Berlin, Germany: Springer.

25. Chapman CR, Casey KL, Dubner R, Foley KM, Gracely RH (1985) Reading AE Pain measurement: an overview. Pain 22(1): 1-31.

26. Gårdmark M, Höglund AU, Hammarlund-Udenaes M (1998) Aspects on tail-flick, hot-plate and electrical stimulation tests for morphine antinociception. Pharmacol Toxicol 83(6): 252-258.

27. Fan S, Ali NA, Basri DF (2014) Evaluation of analgesic activity of the methanol extract from the galls of Quercus infectoria (Olivier) in rats. Evidence-Based Complementary and Alternative Medicine 2014: 6.

28. Winter CA, Risley EA, Nuss GW (1962) Carrageenaninduced oedema in the hind paw of the rat as an assay for anti-inflammatory activity. Proc Soc Exp Biol Med 111: 544-547. 


\section{Journal of Natural \& Ayurvedic Medicine}

29. Jongwon C, Hyun-Ju J, Kyung-Tae L, Hee-Juhn P (2005) Antinociceptive and anti-inflammatory effects of the saponin and sapogenins obtained from the stem of Akebia quinata. J Med Food 8(1): 78-85.

30. Midddleton (1998) Effect of plant flavonoids on immune and inflammatory cell function. Adv Exp Med Biol 439: 175-182.
31. Manthey JA, Guthrie N, Grohmann K (2001) Biological properties of citrus flavonoids pertaining to cancer and inflammation. Curr Med Chem 8(2): 135-153.

32. Viana GSB, Matos FJA, Bandeira MAM, Rao VNS (1995) Aroeira-do-Sertao (Myracrodruonurundeuva Fr. All). EstudoBotanico, Farmacognóstico, Químico e Farmacológico. Fortaleza, EUFC, pp: 160. 